\title{
BRPKM
}

Buletin Riset Psikologi dan Kesehatan Mental

http://e-journal.unair.ac.id/index.php/BRPKM

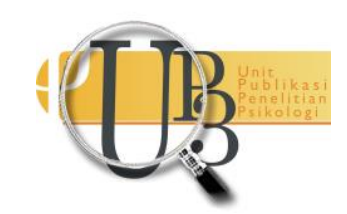

ARTIKEL PENELITIAN

\section{Pengaruh Mindfulness terhadap Psychological Well-Being pada Emerging Adulthood}

\section{BALQIS AISYIYAH \& VERONIKA SUPRAPTI*}

Departemen Psikologi Pendidikan dan Perkembangan, Fakultas Psikologi Universitas Airlangga

\begin{abstract}
ABSTRAK
Penelitian ini bertujuan untuk menguji pengaruh mindfulness terhadap psychological well-being pada emerging adulthood. Penelitian ini melibatkan 332 responden dengan rentan usia 18-25 tahun. Pengumpulan data dilakukan dengan menggunakan metode survei. Alat pengumpulan data ialah kuisioner skala FFMQ (Five Facets Mindfulness Questionnaire) dan skala PWBS (Psychological Well-Being Scale). Teknik analisis data yang digunakan adalah uji regresi dengan simple linear regression menggunakan bantuan program Jamovi 1.6.3. Hasil analisis dalam penelitian ini memiliki nilai signifikansi (p) sebesar <.001 dengan koefisien regresi $\left(\mathrm{R}^{2}\right)$ sebesar 0.379 . Hasil tersebut menunjukkan bahwa mindfulness memiliki pengaruh signifikan terhadap psychological well-being pada emerging adulthood.
\end{abstract}

Kata kunci: dewasa awal, kesejahteraan psikologis, rasa sadar

\section{ABSTRACT}

This study aims to examine the effect of mindfulness towards psychological well-being among emerging adulthood. The study involves 322 respondents in age 18 - 25. The data collection tools is the FFMQ (Five Facets Mindfulness Questionnaire) and the PWBS (Psychological Well-Being Scale). The data analysis technique is the regression with simple linear regression using the help of Jamovi 1.6.3. program. The result of the analysis in thi s study have significance value (p) of $<.001$ with a regression coefficient $\left(R^{2}\right)$ of 0.379. The results indicate that mindfulness has significant effect on psychological well-being in emerging adults.

Keywords: emerging adulthood, mindfulness, psychological well-being

Buletin Penelitian Psikologi dan Kesehatan Mental (BRPKM), 2021, Vol. 1(1), 359-369

*Alamat korespondensi: Fakultas Psikologi Universitas Airlangga, Kampus B Universitas Airlangga Jalan Airlangga 4-6 Surabaya 60286. Surel: veronika.suprapti@psikologi.unair.ac.id

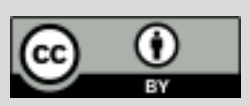

Naskah ini merupakan naskah dengan akses terbuka dibawah ketentuan the Creative Common Attribution License (CC-BY-4.0) (http://creativecommons.org/licenses/by/4.0), sehingga penggunaan, distribusi, reproduksi dalam media apapun atas artikel ini tidak dibatasi, selama sumber aslinya disitir dengan baik. 


\section{PEN D A H U L U A N}

Menurut Erikson (1950, 1968); Miller (2011) individu dihadapkan dengan berbagai masalah pada setiap fase perkembangan hidup, dengan harapan terdapat perubahan pespektif ketika memasuki fase berikutnya. Peralihan dari masa remaja ke masa dewasa merupakan masa yang penting bagi individu, karena pada masa tersebut individu mulai mengeksplorasi diri, hidup mandiri dari orang tua, mengembangkan sistem nilai-nilai, dan membentuk hubungan (Papalia \& Feldman, 2014; Rosalinda \& Michael, 2019).

Fase transisi antara remaja menuju dewasa muda sering dikenal dengan istilah emerging adulthood. Emerging adulthood merupakan transisi masa remaja ke dewasa yang terjadi dari sekitar usia 18 sampai 25 tahun (Arnett, 2006, 2007; Santrock, 2013). Emerging adulthood merupakan tahap transisi dimana individu merasa seperti orang dewasa namun tidak seperti orang dewasa. Dalam masa transisi ini, individu sedang dalam proses mengembangkan kapasitas, keterampilan, dan kualitas karakter yang dianggap oleh budaya mereka diperlukan untuk menyelesaikan transisi ke masa dewasa (Arnett, 1998; Miller, 2011).

Salah satu tugas perkembangan dari emerging adulthood adalah memiliki banyak kesempatan untuk mengeksplorasi identitas di bidang cinta, pekerjaan, serta pandangan dunia (Arnett, 2000). Banyaknya perubahan yang diakibatkan oleh eksplorasi dapat membuat kehidupan individu emerging adulthood menjadi tidak stabil. Pada masa ini individu sering merasa tidak jelas mengenai langkah selanjutnya, sehingga terus-menerus mengubah rencana mereka. Dengan setiap perubahan yang terjadi pada setiap rencana mereka, individu emerging adulthood banyak belajar untuk lebih mengenali dirinya sendiri (Miller, 2011).

Masa emerging adulthood biasanya digambarkan sebagai masa perkembangan yang dikaitkan dengan kesejahteraan psikologis. Beberapa individu mengalami tingkat kesejahteraan psikologis yang baik, sementara itu banyak juga yang mengalami penurunan pada kesejahteraan psikologis. Hal ini biasanya terjadi karena ketidakpastian dan kekhawatiran akan masa depan individu (Ozer \& Schwartz, 2020; Schwartz, 2016). Ryff (1989) mengemukkan bahwa gambaran tentang karakteristik orang yang memiliki kesejahteraan psikologis merujuk pada pandangan Rogers (1961) mengenai orang yang berfungsi penuh (fully functioning person), pandangan Maslow (1968) mengenai aktualisasi diri (selfactualization), pandangan Jung mengenai individuasi, konsep Allport (1961) mengenai kematangan, juga sesuai dengan konsep Erikson mengenai gambaran psikososial. Psychological well-being dapat ditandai dengan individu merasakan kebahagiaan, kepuasaan hidup, dan tidak adanya tanda-tanda depresi (Ryff, 1995). Bradburn (1969); Ryff (1995) mengemukakan kebahagiaan merupakan hasil dari kesejahteran psikologis dan merupakan tujuan yang tertinggi yang ingin dicapai oleh setiap manusia. Berdasarkan gambaran psychological well-being yang tinggi dan rendah, maka individu pada emerging adulthood diharapkan memiliki psychological well-being yang baik agar terhindar dari depresi, mempunyai kepuasan hidup, dan kebahagiaan yang tinggi.

Balzarie \& Nawangsih (2019); Mirowsky \& Ross (1999); Tanner dkk. (2008) dalam penelitiannya mencoba membandingkan antara emerging adulthood dengan tahapan perkembangan selanjutnya. Ditemukan hasil bahwa tingkat terjadinya depresi lebih dialami pada usia 20-an daripada di rentang usia lainnya. Menurut Data Riset Kesehatan Dasar tahun 2013 (Kemenkes, 2016) terdapat sekitar 14 juta orang atau 6\% dari jumlah penduduk di Indonesia pravelansi gangguan 4 mental yang ditunjukkan dengan gejala-gejala depresi dan kecemasan untuk rentan usia 15 tahun ke atas. Mahasiswa juga termasuk pada masa emerging adulthood, dimana biasanya rentan usia mahasiswa berkisar di usia 1825 tahun (Arnett, 2000). Hardjosoesanto dkk. (2017); Sholikhah dkk. (2019) dalam penelitiannya

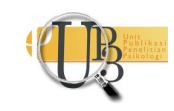


menunjukkan bahwa pravelensi depresi pada mahasiswa yang berada di Universitas Diponegoro sebesar 27,3\%. Maulida (2012); Sholikhah dkk. (2019) dalam penelitiannya menujukkan bahwa angka pravelensi depresi mahasiswa di Universitas Indonesia sebesar 84\%. Balzarie \& Nawangsih (2019) dalam penelitiannya melakukan studi awal dengan 87 mahasiswa yang berada di Bandung. Responden menyatakan bahwa mereka sering kali stres, khawatir dan merasa cemas terhadap hidupnya. Mereka merasa kehidupannya tidak maju dan merasa tidak suka dengan keadaan hidupnya.

Kurniasari dkk. (2019) dalam penelitiannya menyebarkan kuisioner kepada dewasa awal atau emerging adulthood di Bandung. Ditemukan bahwa 64,44\% individu merasa mudah khawatir dalam mengemukakan sesuatu, 53\% individu mengalami perasaan takut, pemalu, dan mudah bingung, 51\% mengalami ketakutan tidak dapat memenuhi harapan dari orang tua, 42,2\% individu sering melamun dan berkhayal, 44,44\% mengalami rendah diri, dan sebanyak 33,33\% kurang terbuka dengan orang lain. Selain itu, terdapat hasil wawancara dengan responden mengenai masalah yang dialami, dan salah satu responden merasa ingin mengakhiri hidupnya karena permasalahan keluarga. Hasil dari penyebaran kuisioner dan wawancara yang dilakukan ini menunjukkan terdapat gejala rendahnya kesejahteraan psikologis. Dari penjelasan sebelumnya, dapat dikatakan bahwa masih banyak individu emerging adulthood memiliki kesejahteraan psikologis yang rendah.

Dari penjalasan diatas, ketika individu emerging adulthood memiliki kesejahteraan psikologis yang rendah, dapat terkait dengan tugas perkembangan utama, yaitu dalam hal karir dan pendidikan atau dalam membangun dan mempertahankan hubungan intim. Hal ini dapat menyebabkan pesimisme terhadap masa depan dan ekspektasi yang kemudian meningkatkan strategi maladaptif ketika mengalami kesulitan atau kepasifan (Salmela-Aro dkk., 2008; Lolombulan dkk., 2020). 5 tugas utama dari periode perkembangan ini adalah berkurangnya ketergantungan dengan orang tua dan meningkatnya hubungan dengan teman sebaya dan pasangan romantis, serta mencapai pendidikan, pekerjaan dan kemandirian finansial di sisi lain. Tujuan dari tantangan ini diperlukan untuk transisi yang sukses dari masa remaja ke dewasa, sedangkan jika individu mengalami kegagalan dapat mengarah pada risiko kerugian perkembangan dan masalah di kemudian hari (Salmela-Aro dkk., 2008; Schulenberg dkk., 2004).

Menurut Ryff (1989) kesejahteraan psikologis (psychological well-being) merupakan hasil evaluasi atau penilaian individu terhadap dirinya sendiri yang dipengaruhi oleh pengalaman hidup dan harapan yang bersangkutan, dan digunakan untuk menggambaran kesehatan psikologisnya berdasarkan pemenuhan fungsi psikologi positif. Kesejahteraan psikologis (psychological well-being) dibagi menjadi enam dimensi utama yaitu, sejauh mana individu memiliki kualitas hubungan positif dengan orang lain (positive relation with others), kemampuan individu menerima dirinya sendiri (self-acceptance), memiliki tujuan hidup (purpose in life), mampu tumbuh secara personal (personal growth), mampu mengendalikan lingkungan (environmental mastery) dan menjadi pribadi yang mandiri (autonomy) (Ryff, 1989). Setiap dimensi dari psychological well-being memberikan tantangan yang berbeda pada tiap individunya ketika mereka berusaha untuk berfungsi secara positif (Keyes dkk., 2002; Ryff, 1989; Ryff \& Keyes, 1995).

Mengingat terdapat keberagaman kesejahteraan psikologis pada tiap individu, maka dibutuhkan eksplorasi mengenai faktor yang berperan dalam kesejahteraan psikologis individu. Terdapat beberapa faktor yang mempengaruhi psychological well-being, yaitu usia, jenis kelamin, pemaknaan hidup (Ryff, 1995), kepribadian (Keyes dkk., 2002), perbedaan budaya (Ryff, 1989). Namun, dalam beberapa riset satu dekade terakhir, terdapat beberapa kajian mengenai mindfulness yang mempengaruhi kesejahteraan psikologis seseorang (Savitri \& Listiyandini, 2017). Mindfulness menangkap sejauh mana 
individu memperhatikan kesadaran (consciousness) (Baer dkk., 2006; Lee \& Chao, 2012) dan telah terbukti dapat memprediksi peningkatan psychological well-being (Brown \& Ryan, 2003; Lee \& Chao, 2012). Sejumlah manfaat telah dikaitkan dengan peningkatan mindfulness seperti peningkatan kesejahteraan psikologis dan kesehatan fisik, kualitas hubungan yang lebih baik, dan peningkatan regulasi diri (Brown dkk., 2007; Ostafin dkk., 2015).

Menurut Brown \& Ryan (2003) mindfulness merupakan kehadiran kesadaran yang melekat dan melibatkan pengalaman dari waktu ke waktu. Baer dkk. (2006); Brown \& Ryan (2003); Kabat-Zinn (1990); Linehan (1993); Marlatt \& Kristeller (1999) mindfulness merupakan merupakan peningkatan kesadaran dengan berfokus pada pengalaman saat ini (present-moment awareness) serta penerimaan tanpa memberikan penilaian (nonjudgmental or acceptance way). Baer dkk. (2006) mengatakan bahwa mindfulness terdiri dari 5 dimensi, antara lain mengamati proses mental dan stimulus sekitar (observing), mengungkapkan pengalaman dengan kata-kata yang tepat (describing), melibatkan diri sepenuhnya dalam aktivitas tanpa membagi-bagi perhatian (acting with awareness), menerima perasaan dan pikiran tanpa memberikan penilaian (nonjudging of inner experience), dan menghindari reaksi otomatis atau reaktif dalam menanggapi peristiwa (nonreacting of inner experience).

Beberapa penelitian telah mengungkapkan manfaat dari mindfulness dalam mendukung kebutuhan perkembangan. Misalnya, pada masa transisi remaja ke dewasa, mindfulness berhubungan dengan arti penting yang meningkatkan dalam mengeksplorasi dan mengevaluasi nilai-nilai pribadi, mengingat bahwa mindfulness dapat memungkinkan individu emerging adulthood untuk lebih memperhatikan pengalaman batin dan luar mereka. Dengan melakukan ini, individu emerging adulthood dapat mengembangkan pemahaman mengenai nilai-nilai inti mereka, yang dapat menuntun mereka untuk membuat pilihan yang konsisten dengan diri mereka, pilihan-pilihan yang membuat mereka merasa lebih percaya diri (Rogers, 2013). Penelitian lain telah mendukung hubungan ini, dan juga mengemukakan bahwa mindfulness dapat mengurangi hubungan antara ketidakstabilan, fokus diri, dan perasaan "diantara" dan pengalaman keraguan diri (Peer \& McAuslan, 2015; Yang dkk., 2017).

Istiqomah (2020) dalam penelitiannya mengemukakan bahwa mindfulness berkorelasi positif dengan psychological well-being pada mahasiswa baru yang tinggal di pondok pesantren. Hal ini menunjukkan bahwa semakin tinggi mindfulness, maka semakin tinggi pula psychological well-being individu. Erpiana \& Fourianalistyawati (2018) dalam penelitiannya mengemukakan bahwa trait mindfulness berpengaruh signifikan terhadap enam dimensi dari psychological well-being. Pertama, dimensi dari trait mindfulness yaitu observing, describing, dan non-reactivity to inner experience berperan signifikan terhadap dimensi psychological well-being yaitu self-acceptance. Kedua, dimensi dari trait mindfulness yaitu observing dan acting with awareness menunjukkan peran yang signifikan terhadap empat dimensi dari psychological well-being yaitu positive relation with others, autonomy, environmental mastery, dan purpose in life. Ketiga, dimensi dari trait mindfulness yaitu acting with awareness berperan signifikan terhadap dimensi dari psychological well-being yaitu personal growth.

Berdasarkan argumentasi-argumentasi yang telah dijelaskan sebelumnya, penulis tertarik untuk meneliti lebih lanjut mengenai apakah mindfulness memiliki pengaruh terhadap psychological well-being pada emerging adulthood. Berdasarkan tinjauan literatur yang dilakukan oleh penulis, terdapat hubungan positif antara mindfulness dengan psychological well-being, dan dimensi mindfulness berperan secara signifikan terhadap dimensi psychological well-being. Dari berbagai faktor yang dapat mempengaruhi mindfulness, penulis memilih untuk meneliti mindfulness dikarenakan pada penelitian ini ingin mencoba untuk melihat apakah mindfulness memiliki pengaruh terhadap psychological well- 
being pada emerging adulthood di Indonesia. Selain itu, belum banyak penelitian mengenai pengaruh mindfulness terhadap psychological well-being pada emerging adulthood di Indonesia. Maka dari itu, peneliti ingin melakukan penelitian mengenai pengaruh mindfulness terhadap psychological well-being pada emerging adulthood dengan populasi di Indonesia.

Tujuan dilakukanya penelitian untuk mengetahui pengaruh mindfulness terhadap psychological wellbeing pada emerging adulthood. Adapun pertanyaan dalam penelitian ini adalah $\left(\mathrm{H}_{\mathrm{a}}\right)$ mindfulness memiliki pengaruh signifikan terhadap psychological well-being pada emerging adulthood, dan $\left(\mathrm{H}_{0}\right)$ mindfulness tidak memiliki pengaruh signifikan terhadap psychological well-being pada emerging adulthood.

\section{E T ODE}

Tipe penelitian ini menggunakan pendekatan kuantitatif. Penelitian yang menggunakan metode kuantitatif menekankan pada data-data kuantitatif yang dikumpulkan melalui prosedur pengukuran dan diolah dengan metode analisis statistika (Azwar, 2018). Jenis penelitian ini adalah explanatory research, dimana hasil dan proses dalam penelitian ini besifat untuk menejalskan mengenai hubungan antar variabel yang diteliti serta adanya uji hipotesis (Singarimbun \& Effendi, 1989). Tipe penelitian eksplanatori juga dapat menjelaskan gagasan terjadinya peristiwa. Dalam penelitian ini, penulis menggunakan dua variabel yaitu variabel dependen (X) mindfulness dan variabel independen (Y) psychological well-being. Dua variabel ini digunakan untuk mengetahui pengaruh mindfulness terhadap psychological well-being pada emerging adulthood.

Teknik sampling yang digunakan dalam penelitian ini adalah purposive sampling, yaitu teknik dimana pengambilan sampel dilakukan berdasarkan kriteria tertentu sehingga siapa saja yang termasuk dalam kriteria yang sudah ditentukan dapat megisi kuisioner yang telah disebarkan oleh peneliti (Neuman, 2015). Terdapat pula kriteria untuk partisipan dalam penelitian ini yaitu laki-laki atau perempuan yang berusia 18-25 tahun, Warga Negara Indonesia (WNI), dan tinggal di Indonesia. Dalam penelitian ini, penulis menggunakan analisi $G^{*}$ Power dengan perangkat $G^{*}$ Power 3.1.9.7 untuk menentukan jumlah sampel. Hal ini dilakukan untuk menyesuaikan nilai power yang ingin didapatkan untuk memperkuat hasil penelitian (Navarro \& Foxcroft, 2019). A priori power analysis dengan jenis tes linear multiple regression: Fixed model, $R 2$ deviation from zero. Dengan menggunakan teknik ini, dapat memberikan informasi tentang ukuran sampel yang dibutuhkan guna mendeteksi effect size sebesar 0,15 dengan statistical power 95\% dan alpha 5\% dengan satu prediktor yang digunakan. Berdasarkan hasil kalkulasi $G^{*}$ Power, jumlah sampel yang dibutuhkan dalam penelitian ini sebanyak 89 orang. Sehingga, dapat diartikan jumlah sampel dalam penelitian ini minimal sebanyak 89 orang. Sebelum partisipan mengisi dua instrumen yang disediakan oleh penulis, partisipan harus mengisi informed consent pada bagian pertama dan kemudian mengisi dua instrumen alat ukur pada bagian selanjutnya.

Alat ukur yang digunakan dalam penelitian ini untuk variabel dependen yaitu mindfulness adalah FFMQ (Five Facet Mindfulness Questionnaire) milik Baer dkk. (2006) yang telah digunakan dalam penelitian (Jannah, 2019) dengan judul "Hubungan Mindfulness dan Penerimaan Diri pada Remaja dengan Orang Tua Tunggal" yang terdiri dari 39 aitem dengan 5 pilihan jawaban ( 1 = Tidak Pernah, $5=$ Sangat Sering). Sedangkan alat ukur untuk variabel independen yaitu psychological well-being adalah PWBS (Psychological Well-Being Scale) milik Ryff (1989) yang didapatkan dari Bagian Riset dan Pengukuran Fakultas Psikologi Universitas Tarumanegara yang digunakan dalam penelitian (Hilke, 2019) dengan judul "Hubungan Dukungan Sosial dengan Psychological Well-Being pada Mahasiswa Kedokteran Dewasa Awal" yang terdiri dari 31 aitem dengan 5 pilihan jawaban (1 = Tidak Setuju, 5 = Sangat Setuju).

Buletin Riset Psikologi dan Kesehatan Mental (BRPKM)

Tahun, Vol. X(no), pp 
Teknik validitas yang digunakan dalam penelitian ini menggunakan validitas yang suah dilakukan oleh peneliti sebelumnya. Teknik validitas pada alat ukur mindfulness menggunakan pendekatan content validity, yang dilakukan dengan bantuan professional judgement yaitu dosen Fakultas Psikologi Universitas Muhammadiyah Malang. Sedangkan pada alat ukur psychological well-being menggunakan pendekatan construct validity yang dilakukan oleh Bagian Riset dan Pengukuran Fakultas Psikologi Universitas Tarumanegara.

Reliabilitas dari kedua alat ukur ini dilakukan peneliti sebelumnya menggunakan teknik Cronbach's alpha. Hasil uji reliabilitas pada alat ukur mindfulness adalah $\alpha=0,869$ sehingga instrumen dapat dikatakan reliabel. Hasil uji reliabilitas pada alat ukur psychological well-being dilakukan perdimensi. Hasil uji reliabilitas pada dimensi self-acceptance adalah $\alpha=0.743$ sehingga instrumen pada dimensi ini dapat dikatakan reliabel. Hasil uji reliabilitas pada dimensi positive relation with others adalah $\alpha=0.724$ sehingga instrumen pada dimensi ini dapat dikatakan reliabel. Hasil uji reliabilitas pada alat dimensi autonomy adalah $\alpha=0.634$ sehingga instrumen pada dimensi ini dapat dikatakan reliabel. Hasil uji reliabilitas pada dimensi environmental mastery adalah $\alpha=0.755$ sehingga instrumen pada dimensi ini dapat dikatakan reliabel. Hasil uji reliabilitas pada dimensi purpose in life adalah $\alpha=0.707$ sehingga instrumen pada dimensi ini dapat dikatakan reliabel. Hasil uji reliabilitas pada dimensi personal growth adalah $\alpha=0.663$ sehingga instrumen pada dimensi ini dapat dikatakan reliabel.

\section{HAS I L P E N EL I T IAN}

\section{Uji Deskriptif}

Uji deskriptif pada penelitian ini menggunakan partisipan $\mathrm{N}=332$. rata-rata pada variabel mindfulness adalah 117, sedangkan pada variabel psychological well-being adalah 110. Nilai maximum dan minimum pada variabel mindfulness adalah 149 dan 91, sedangkan pada variabel psychological well-being adalah 146 dan 50. Nilai range pada variabel mindfulness adalah 58, sedangkan pada variabel psychological well-being adalah 96. Nilai standar deviasi pada variabel mindfulness adalah 10.7, sedagkan pada variabel psychological well-being adalah 15.7. Partisipan dalam penelitian ini $15.4 \%$ adalah laki-laki, dan $84.6 \%$ adalah perempuan.

\section{Uji Linearitas}

Setelah uji asumsi terpenuhi, penulis melakukan uji linearitas untuk menguji bahwa hubungan antara variabel independen dan variabel dependen adalah linear. Pada penelitian ini, uji linearitas yang dilakukan menggunakan scatterplot. Jika persebaran titik pada scatterplot tidak membentuk suatu pola tertentu, maka hubungan antar kedua variabel dapat dikatakan linear. Pada penelitian ini, dapat dikatakan bahwa kedua variabel cukup linear.

\section{Uji Analisis Regresi Sederhana}

Uji asumsi dan uji linearitas terpenuhi dan yang terakhir adalah melakukan uji analisis regresi sederhana. Data yang diperoleh dalam penelitian ini menunjukkan $(F(1,330)=218$, nilai $p>.001)$ nilai koefisien regresi $\left(\mathrm{R}^{2}\right)$ sebesar 0.397. Nilai ini menunjukkan varians mindfulness overlap sebanyak 39.7\% dengan variabel psychological well-being. Variabel mindfulness menghasilkan $(B=0.925, C I 95=[1,105]$, $\mathrm{SE}=0.06 \mathrm{t}=14.75$ nilai $\mathrm{p}<0.001$ ) yang berarti menunjukkan nilai yang positif, sehingga ketika mindfulness meningkat, maka psychological well-being juga akan meningkat. 


\section{I S K U S I}

Hasil dari penelitian ini menunjukkan bahwa mindfulness berpengaruh terhadap psychologocial wellbeing pada emerging adulthood. Hasil penelitian ini bersejajaran dengan asumsi sebelumnya yang menyatakan terdapat pengaruh yang signifikan antara mindfulness terhadap psychological well-being. Bränström dkk. (2011) mengemukakan terdapat beberapa kemungkinan bagaimana mindfulness dapat mempengaruhi fungsi psikologis. Menurut Ryff (1989) kesejahteraan psikologis (psychological welleing) merupakan hasil evaluasi atau penilaian individu terhadap dirinya sendiri yang dipengaruhi oleh pengalaman hidup dan harapan individu yang bersangkutan, dan digunakan untuk menggambarkan kesehatan psikologisnya berdasarkan pemenuhan fungsi psikologi positif. Menjadi seseorang yang mindful dapat mengarahkan pada pandangan dan pikiran sebagai sesuatu yang sementara, dimana seseorang dapat melihat pikirannya sebagai "hanya pikiran" dan mempengaruhi sebagai "hanya perasaan". Perspektif ini dapat menyebabkan pola pikir yang tidak otomatis dan dapat mengarahkan pada regulasi yang lebih efektif dan mengurangi reaktivitas terhadap keadaan yang tidak menyenangkan. Dengan mindfulness, seseorang dapat menerima keberadaan dengan apa adanya, dan ini merupakan lawan dari memiliki kebutuhan untuk mengubah keadaan yang tidak menyenangkan saat ini dan berjuang untuk masa depan, untuk mendapatkan tujuan yang lebih menyenangkan. Seseorang yang mindful akan merasa puas dengan situasi saat ini tanpa tanpa terus-menerus berusaha menuju keadaan yang mungkin di masa depan dengan sendirinya menghasilkan kesejahteraan dan kebahagiaan yang lebih besar yang tidak bergantung pada pengalaman (Bränström dkk., 2011).

Savitri \& Listiyandini (2017) dalam penelitiannya mengemukakan mindfulness berpengaruh secara signifikan terhadap kesejahteraan psikologis pada remaja. Dimensi mindfulness paling berkontribusi khususnya terhadap dimensi penguasaan lingkungan (environmental mastery) yaitu sebesar $23 \%$. Hal ini mengindikasikan bahwa remaja yang lebih mindful dapat mengatur lingkungan, memiliki kontrol terhadap aktivitas yang dijalani, menggunakan secara efektif kesempatan dalam lingkungan, mampu memilih, serta menciptakan konteks yang sesuai dengan kebutuhan dan nilai yang dimiliki. Selain itu, mindfulness juga berkontribusi terhadap dimensi lain dari kesejahteraan psikologis seperti tujuan hidup (purpose in life), pertumbuhan diri (personal growth), penerimaan diri (self-acceptance), kemandirian (autonomy), dan hubungan positif dengan orang lain (positive relation with others). Menurut teori yang menjadi acuan dalam penelitian ini yaitu teori emerging adulthood Arnett, ciri utama individu pada masa ini adalah mereka memiliki banyak kesempatan untuk mengeksplorasi identitas di bidang cinta, pekerjaan, dan pandangan dunia (Arnett, 2000). Banyaknya perubahan yang diakibatkan oleh eksplorasi dapat membuat kehidupan individu pada emerging adulthood ini menjadi sangat tidak stabil (Miller, 2011). Emerging adulthood merupakan titik kritis dalam perkembangan kehidupan manusia. Temuan dari penelitian life-span menunjukkan emerging adulthood merupakan masa kritis dalam perkembangan saat penanda peristiwa kehidupan paling mungkin terjadi (Furlong, 2009; Grob dkk., 2001). Peristiwa yang dialami pada masa emerging adulthood akan terintegrasi ke dalam identitas dan ingatan individu lebih daripada peristiwa yang terjadi selama tahap kehidupan yang lebih muda dan lebih tua (Furlong, 2009).

\section{S I M P U L A N}

Berdasarkan serangkaian proses pengujian dan analisis yang telah dilakuan, diketahui bahwa terdapat pengaruh mindfulness terhadap psychological well-being pada emerging adulthood. Dapat disimpulkan bahwa semakin tinggi mindfulness maka psychological well-being akan semakin tinggi, dan sebaliknya semakin rendah mindfulness maka semakin rendah psychological well-being. 


\section{U C A P A N T ERIMA KASI H}

Penulis ingin mengucapkan terima kasih sebesar-besarnya terhadap pihak-pihak membantu dalam penulisan naskah ini. Terima kasih kepada Dra. Veronika Suprapti, MS. Ed, Psikolog, selaku dosen pembimbing penulis, kepada seluruh dosen pengajar dan staf di Fakultas Psikologi Universitas Airlangga, partisipan penelitian ini, dan seluruh pihak yang tidak dapat disebutkan satu-persatu.

\section{DEKLARASI POTENSI TERJADINYA KONFLIK KEPENTINGAN}

Balqis Aisyiyah dan Veronika Suprapti tidak bekerja, menjadi konsultan, memiliki saham, atau menerima dana dari perusahaan atau organisasi manapun yang mungkin akan mengambil untung dari diterbitkannya naskah ini.

\section{PUST AKA ACUAN}

Allport, G. W. (1961). Pattern and Growth in Personality. Holt, Rinehart \& Winston.

Arnett, Jeffrey Jensen. (1998). Learning to Stand Alone: The Contemporary American Transition to Adulthood in Cultural and Historical Context. Human Development, 41(5-6), 295-315. https://doi.org/10.1159/000022591

Arnett, Jeffrey Jensen. (2000). Emerging adulthood: A theory of development from the late teens through the twenties. American Psychologist, 55(5), 469-480. https://doi.org/10.1037/0003066X.55.5.469

Arnett, Jeffrey Jensen. (2006). Emerging Adulthood: Understanding the New Way of Coming of Age. American Psychological Association.

Arnett, Jeffrey Jensen. (2007). Arnett-2007-Child_Development_Perspectives. Child Development Perspectives, 1(2), 68-73.

Azwar, S. (2018). Metode Penelitian Psikologi. Pustaka Belajar.

Baer, R. A., Smith, G. T., Hopkins, J., Krietemeyer, J., \& Toney, L. (2006). Using self-report assessment methods to explore facets of mindfulness. Assessment, 13(1), 27-45. https://doi.org/10.1177/1073191105283504

Balzarie, E. N., \& Nawangsih, E. (2019). Kajian Resiliensi pada Mahasiswa Bandung yang Mengalami Quarter Life Crisis. Prosiding Psikologi, 5(2), 494-500.

Bradburn, N. M. (1969). The Structure of Psychological Well-Being. Aldine Publishing Company.

Bränström, R., Duncan, L. G., \& Moskowitz, J. T. (2011). The association between dispositional mindfulness, psychological well-being, and perceived health in a Swedish population-based sample. British Journal of Health Psychology, 16(2), 300-316. https://doi.org/10.1348/135910710X501683

Brown, K. W., \& Ryan, R. M. (2003). The Benefits of Being Present: Mindfulness and Its Role in Psychological Well-Being. Journal of Personality and Social Psychology, 84(4), 822-848. https://doi.org/10.1037/0022-3514.84.4.822

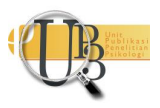


Brown, K. W., Ryan, R. M., \& Creswell, J. D. (2007). Mindfulness: Theoretical foundations and evidence for its salutary effects. Psychological Inquiry, 18(4), 211-237. https://doi.org/10.1080/10478400701598298

Erikson, E. H. (1950). Childhood and Society. Norton.

Erikson, E. H. (1968). Identity, Youth, and Crisis. Norton.

Erpiana, A., \& Fourianalistyawati, E. (2018). Peran Trait Mindfulness terhadap Psychological Well-Being pada Dewasa Awal. Psympathic: Jurnal Ilmiah Psikologi, 5(1), 67-82. https://doi.org/10.15575/psy.v5i1.1774

Furlong, A. (2009). Handbook of Youth and Young Adulthood. Routledge.

Grob, A., Krings, F., \& Bangerter, A. (2001). Life markers in biographical narratives of people from three cohorts: A life span perspective in its historical context. Human Development, 44(4), 171-190. https://doi.org/10.1159/000057057

Hardjosoesanto, Andreas Yohan. AS Sarjana, Widodo. Jusup, I. (2017). Jurnal Kedokteran Diponegoro Hubungan Antara Tingkat Kecemasan Dengan Tingkat Sugestibilitas Pada Mahasiswa Fakultas Kedokteran Tahun Pertama. Innawati Jusup JKD, 6(2), 2540-8844. http://ejournals1.undip.ac.id/index.php/medico

Hilke, A. (2019). Hubungan Dukungan Sosial dengan Psychological Well-Being pada Mahasiswa Kedokteran Dewasa Awal. Universitas Tarumanegara.

Istiqomah, S. (2020). Hubungan Antara Mindfullness Dan Psychological Well-Being Pada Mahasiswa Baru Yang Tinggal Di Pondok Pesantren X, Y, Dan Z. Empati, 8(4), 127-132.

Jannah, A. M. (2019). Hubungan Mindfulness dan Penerimaan Diri pada Remaja dengan Orang Tua Tunggal. In Fakultas Psikologi Universitas Muhammadiyah Malang.

Kabat-Zinn, J. (1990). Full Catastrophe Living: Using the Wisdom of Your Mind and Body to Face Stress, Pain, and Ilness. Delacorte.

Kemenkes, K. K. R. I. (2016). Peran Keluarga Dukung Kesehatan Mental Jiwa Masyarakat. http://www.depkes.go.id/article/print/161\%0D

Keyes, C. L. M., Shmotkin, D., \& Ryff, C. D. (2002). Optimizing well-being: The empirical encounter of two traditions. Journal of Personality and Social Psychology, 82(6), 1007-1022. https://doi.org/10.1037/0022-3514.82.6.1007

Kurniasari, E., Rusmana, N., \& Budiman, N. (2019). Gambaran Umum Kesejahteraan Psikologis Mahasiswa. Journal of Innovative Counseling: Theory, Practice, and Research, 3(2), 52-58.

Lee, Y. C., \& Chao, H. F. (2012). The role of active inhibitory control in psychological well-being and mindfulness. Personality and Individual Differences, 53(5), 618-621. https://doi.org/10.1016/j.paid.2012.05.001

Linehan, M. M. (1993). Cognitive-Behavioral Treatment of Borderline Personality Disorder. Guilford.

Lolombulan, O., Yuliandari, E., \& Dianovinina, K. (2020). Art therapy untuk menurunkan gejala depresi pada emerging adult dengan ketidakpuasan pada tubuh. Journal of Visual Communication in

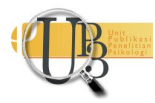


Medicine, 5(1), 94-102. https://doi.org/10.3109/17453058009167125

Marlatt, G. A., \& Kristeller, J. L. (1999). Mndfulness and Meditation. In Integrating Spirituality into Treatment. American Psychological Association.

Maslow, A. H. (1968). Toward a Psychology fo Being (2nd ed). Van Nostrand.

Maulida, A. (2012). Gambaran Tingkat Depresi pada Mahasiswa Program Sarjana yang Melakukan Konseling di Badan Konseling Indonesia. Universitas Indonesia.

Miller, J. L. (2011). The Relationship between Identity Development Processes and Psychological Distress in Emerging Adulthood. In Dissertation.

Mirowsky, \& Ross. (1999). Well-Being Across the Life Course. In Horwitz \& Scheid (Eds.), A Handbook for the Study of Mental Health: Social Context, Theories, and System. Cambridge University Press.

Navarro, D., \& Foxcroft, D. (2019). Learning Statistic with Jamovi: A Tutorial for Psychology Student and Other Beginners. https://doi.org/doi:10.24384/hgc3-7p15

Neuman, W. L. (2015). Metodologi Penelitian Sosial: Pendekatan Kualitatif dan Kuantitatif. PT. Indeks.

Ostafin, B. D., Robinson, M. D., \& Meier, B. P. (2015). Handbook of mindfulness and self-regulation. In Handbook of Mindfulness and Self-Regulation. https://doi.org/10.1007/978-1-4939-2263-5

Ozer, S., \& Schwartz, S. J. (2020). Academic motivation, life exploration, and psychological well-being among emerging adults in Denmark. Nordic Psychology, 72(3), 199-221. https://doi.org/10.1080/19012276.2019.1675088

Papalia, D. E., \& Feldman, R. D. (2014). Menyelami Perkembangan Manusia (2nd ed.). Salemba Humanika.

Peer, J. W., \& McAuslan, P. (2015). Self-Doubt During Emerging Adulthood: The Conditional Mediating Influence of Mindfulness. Emerging Adulthood, 4(3), 176-185. https://doi.org/10.1177/2167696815579828

Rogers, C. R. (1961). On Becoming a Person. Houghton Mifflin.

Rogers, H. B. (2013). Editorial. Koru: Teaching Mindfulness to Emerging Adults, 119, 1-7. https://doi.org/10.1002/tl

Rosalinda, I., \& Michael, T. (2019). Pengaruh Harga Diri Terhadap Preferensi Pemilihan Pasangan Hidup Pada Wanita Dewasa Awal Yang Mengalami Quarter-Life Crisis. JPPP - Jurnal Penelitian Dan Pengukuran Psikologi, 8(1), 20-26. https://doi.org/10.21009/jppp.081.03

Ryff, C. D. (1989). Happiness is everything, or is it? Explorations on the meaning of psychological wellbeing. Journal of Personality and Social Psychology, 57(6), 1069-1081. https://doi.org/10.1037/0022-3514.57.6.1069

Ryff, C. D. (1995). Psychological Well-Being in Adult Life. Current Directions in Psychological Science, 4(4), 99-104. https://doi.org/10.1111/1467-8721.ep10772395

Ryff, C. D., \& Keyes, C. L. M. (1995). The Structure of Psychological Well-Being Revisited. Journal of Personality and Social Psychology, 69(4), 719-727. https://doi.org/10.1037/0022-3514.69.4.719

Salmela-Aro, K., Aunola, K., \& Nurmi, J.-E. (2008). Trajectories of depressive symptoms during emerging

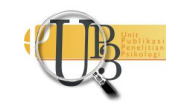


adulthood: Antecedents and consequences. European Journal of Developmental Psychology, 5(4), 439-465. https://doi.org/10.1080/17405620600867014

Santrock, J. W. (2013). Life-span Development 13th Edition. Mc Graw-Hill.

Savitri, W. C., \& Listiyandini, R. A. (2017). Mindfulness dan Kesejahteraan Psikologis pada Remaja. Psikohumaniora: Jurnal Penelitian Psikologi, 2(1), 43. https://doi.org/10.21580/pjpp.v2i1.1323

Schulenberg, J. E., Bryant, A. L., \& O'Malley, P. M. (2004). Taking hold of some kind of life: How developmental tasks relate to trajectories of well-being during the transition to adulthood. Development and Psychopathology, 16(4), 119-1140. https://doi.org/10.1017/S0954579404040167

Schwartz, S. J. (2016). Turning point for a turning point: Advancing emerging adulthood theory and research. Emerging Adulthood, 4, 307-317. https://doi.org/10.1177/2167696815624640

Sholikhah, H. F., Pratama, R. A., Ayodhya, G., \& Astutik, E. (2019). Gambaran Depresi Mahasiswa Program Studi Kesehatan Masyarakat PSDKU Universitas Airlangga di Bayuwangi. Journal of Community Mental Health and Public Policy, 1-9.

Singarimbun, M., \& Effendi, S. (1989). Metode Penelitian Survey. LP3ES.

Tanner, J. L., Arnett, J. J., \& Leis, J. A. (2008). Emerging Adulthood: Learning and Development During the First Stage of Adulthood. In Handbook of Research on Adult Learning and Development.

Yang, C. chen, Holden, S. M., \& Carter, M. D. K. (2017). Emerging adults' social media self-presentation and identity development at college transition: Mindfulness as a moderator. Journal of Applied Developmental Psychology, 52(August), 212-221. https://doi.org/10.1016/j.appdev.2017.08.006 